the sinoatrial node at the time of conversion from the bidirectional cavopulmonary anastomosis to the Fontan circulation may reduce the prevalence and progression of both early and late atrial arrhythmias (with an incidence as high as $20 \%$ after a conventional Fontan repair ${ }^{6}$ ), atrial thrombus formation, and atrially induced pulmonary venous obstruction. In high-risk patients such as those with increased pulmonary vascular resistance, pulmonary hypertension, and impaired ventricular function, an adjustable fenestration between the extracardiac conduit and the common atrium may be added. ${ }^{10}$

In most cases, prosthetic material in one form or another is necessary when an extracardiac tunnel is constructed to bridge the gap between the IVC and the corresponding branch pulmonary artery. Construction of an extracardiac conduit without use of prosthetic material may be feasible in hearts with situs solitus, levocardia, and L-transposition or L-malposition of the aorta (or, alternatively, situs inversus, dextrocardia, and D-transposition or D-malposition of the aorta) in the presence of an adequately developed main pulmonary artery, as in the case presented here. This modification has all of the advantages of exclusive use of native tissue, including growth potential at pediatric age, as well as reduced risk of thrombus formation (and therefore avoidance of need for anticoagulation), elimination of peel formation, lower infection rate, and reduced cost. Long-term follow-up of the results of this technique will provide further information regarding all these aspects.

\section{REFERENCES}

1. Humes RA, Feldt RH, Porter CJ, Julsrud PR, Puga FJ, Danielson GK. The modified Fontan operation for asplenia and polysplenia syndromes. J THORAC CARdiovasc Surg 1988;96:212-8.

2. Nawa $S$, Teramoto $S$. New extension of the Fontan principle: inferior vena cava-pulmonary artery bridge operation. Thorax 1988;43:1022-3.

3. Giannico S, Corno A, Marino B, et al. Total extracardiac right heart bypass. Circulation 1992;86(Suppl): II110-7.

4. Chang AC, Hanley FL, Wernovsky G, et al. Early bidirectional cavopulmonary shunt in young infants: postoperative course and early results. Circulation 1993;88(Suppl):II149-58.

5. Caspi J, Coles JG, Rabinovich M, et al. Morphological findings contributing to a failed Fontan procedure: twelve-year experience. Circulation 1990;82(Suppl): IV177-82.

6. Driscoll DJ, Offord KP, Feldt RH, Schaff HV, Puga FJ, Danielson GK. Five- to fifteen-year follow-up after Fontan operation. Circulation 1992;85:469-96.

7. de Leval M, Kilner P, Gewillig M, Bull C, McGoon DC. Total cavopulmonary connection: a logical alternative to atriopulmonary connection for complex Fontan operations - experimental studies and early clinical experience. J THORAC CARDIOvasC SurG 1988; 96:682-95.

8. van de Wal HJCM, Tanke RF, Roef MJ. The modified Senning operation for cavopulmonary connection with autologous tissue. J Thorac Cardiovasc Surg 1994;108:377-80.

9. Sarioglu T, Paker T, Türkoglu $\mathrm{H}$, et al. The modified Fontan operation in hearts with atrioventricular valve atresia or common atrioventricular valve-neoseptation of the atriums using a right atrial flap. Cardiol Young 1994;4:353-7.

10. Black MD, van Son JAM, Haas GS. Extracardiac Fontan with adjustable communication. Ann Thorac Surg [In press].

\title{
ATHEROSCLEROTIC LESIONS OF THE GASTROEPIPLOIC ARTERY: ONE CASE REQUIRING POSTOPERATIVE DILATION AND SOME INTERESTING POSTMORTEM OBSERVATIONS
}

\author{
Thierry Carrel, MD, ${ }^{a}$ Franz W. Ammann, MD, ${ }^{\mathrm{b}}$ Jakob Schneider, MD, ${ }^{\mathrm{c}}$ Hannes Domeisen, MD, ${ }^{\mathrm{c}}$ and
} Marko Turina, MD, ${ }^{a}$ Zurich, Switzerland

Use of the right gastroepiploic artery (RGEA) for myocardial revascularization has regained general acceptance since it has been proved that arterial conduits usually are superior to venous bypass grafts. Furthermore, the RGEA can be extremely useful in coronary reopera-

From the Clinic for Cardiovascular Surgery, ${ }^{a}$ Departments of Cardiology $^{\mathrm{b}}$ and Pathology, ${ }^{\mathrm{c}}$ University Hospital, Zurich, Switzerland.

Accepted for publication Feb. 17, 1995.

J ThoraC CARDIOvasC SURG 1995;110:1768-70

Copyright $(C) 1995$ by Mosby-Year Book, Inc.

$0022-5223 / 95 \$ 5.00+0 \quad \mathbf{1 2 / 5 4 / 6 4 3 3 9}$ tions and after stripping of saphenous veins. ${ }^{1-3}$ Early and mid-term experience has been satisfactory, and postoperative angiographic results confirm the clinical findings. ${ }^{4-6}$ However, some areas associated with the RGEA remain only partially known, particularly the incidence and severity of atherosclerosis. Atherosclerosis seems not to be prevalent in this vessel. However, the RGEA can be affected either directly or as a consequence of atherosclerotic lesions (e.g., ulcerations, cholesterol deposits) that develop in the descending thoracic aorta and the celiac trunk.

Case report. A 63-year-old patient with New York Heart Association functional class III angina had severe coronary artery disease involving the three main branches. 


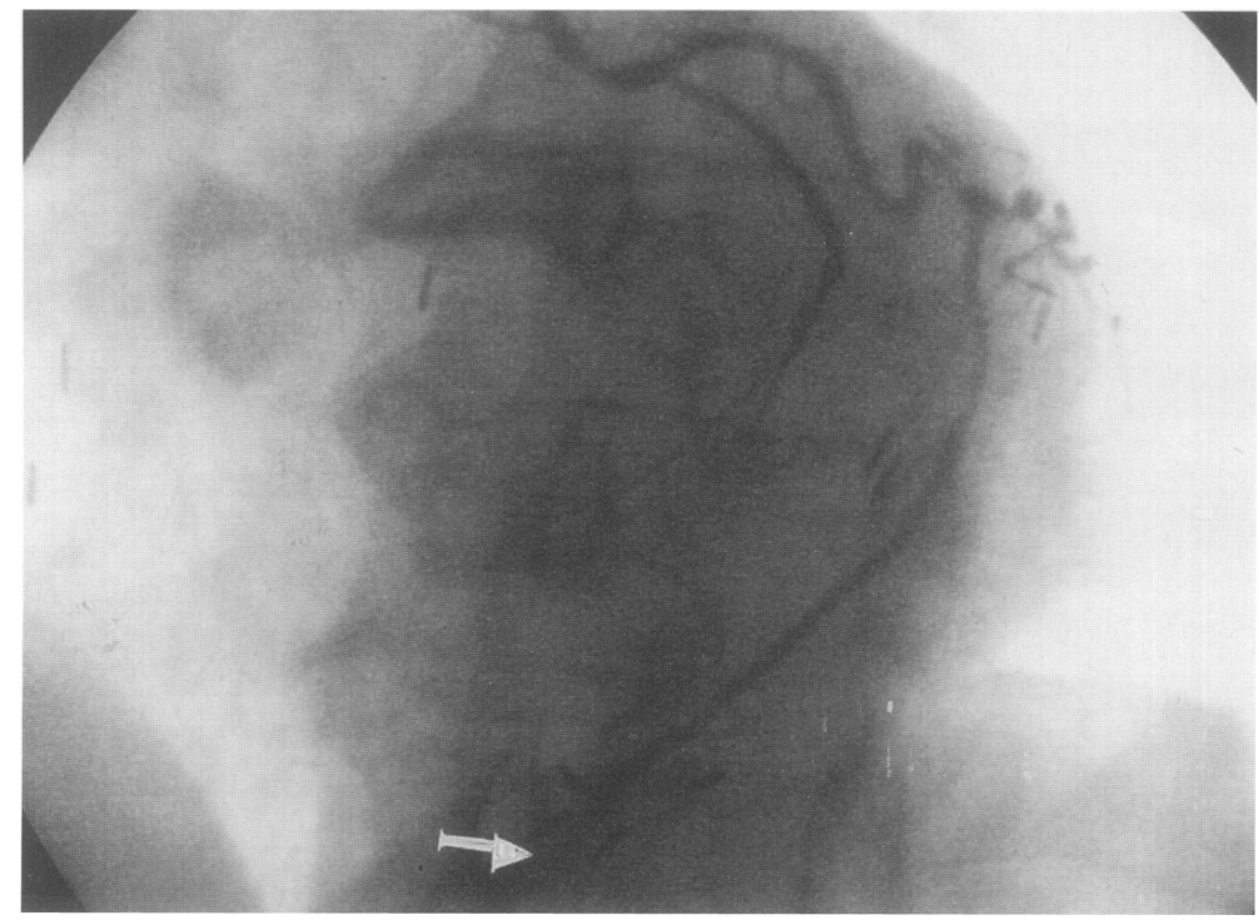

Fig. 1. Postoperative angiogram of RGEA demonstrates early filling of circumflex branch and significant stenosis of RGEA in its proximal segment (white arrow).

He underwent an uncomplicated myocardial revascularization with moderate hypothermic cardiopulmonary bypass and cold blood cardioplegic arrest. The left internal mammary artery (IMA) was grafted to the left anterior descending branch (LAD), the right IMA to the right coronary artery, and the RGEA was anastomosed to the circumflex branch. Venous grafts were not available in this patient.

The RGEA was harvested with the aid of a stapling device and 4-0 silk ligatures. After heparinization, the distal RGEA was divided and cannulated with a soft olive-tipped needle through which a diluted papaverine solution was flushed. Immediately before grafting, RGEA inflow was considered to be normal.

The postoperative course was uncomplicated and the patient was discharged on postoperative day 8. Unfortunately, stress-induced retrosternal pain developed 3 months after the operation. An exercise electrocardiogram demonstrated inferior ischemic changes and angiography showed a $50 \%$ to $75 \%$ stenosis in the proximal segment of the RGEA (Fig. 1). The stenotic lesion was considered to be amenable to percutaneous dilation. This treatment was successful, as assessed by an immediate angiographic result, disappearance of exercise-induced ischemia, and relief of pain. Two years after angioplasty, the patient is free of symptoms. Treatment consists of low-dose salicylic acid and nifedipine $20 \mathrm{mg}$ daily.

Comment. This case and some interesting postmortem observations, to be reported in this article, should focus interest on an important aspect of RGEA, that is, the prevalence of atherosclerosic lesions. In their comprehen-

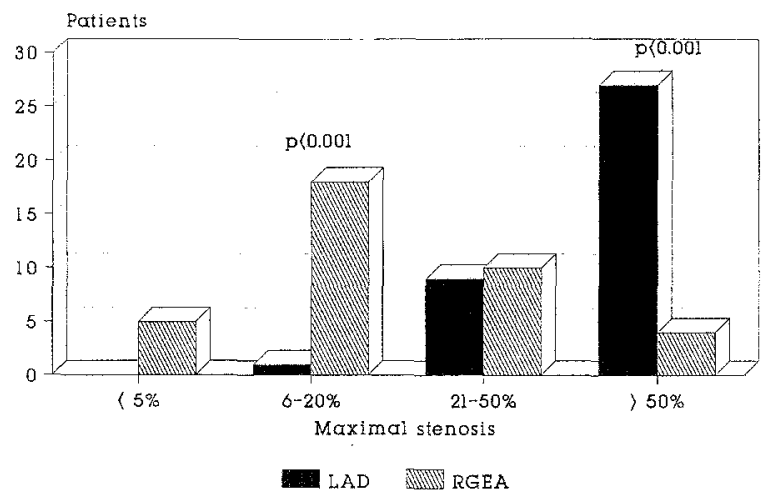

Fig. 2. Incidence and severity of RGEA and $L A D$ lesions in 37 postmortem examinations. Note the high incidence of lesions of greater than $50 \%$ stenosis in RGEA. These changes were found to be independent to age of patient.

sive article about this topic, Suma and Takamashi ${ }^{7}$ concluded that significant luminal narrowing by atherosclerosis is uncommon. The need to dilate a genuine RGEA stenosis after coronary revascularization seems to be rare.

Recently, the incidence, severity, and extent of atherosclerotic changes in the RGEA were assessed in our institution by postmortem examination (37 patients, mean age 64 years) and were compared with the lesions found in the $\mathrm{LAD}$ in the same patients. ${ }^{8}$ Tissue probes 
(three of the LAD and five of the RGEA at 3 to $5 \mathrm{~cm}$ intervals) were fixed in $4 \%$ formalin solution and embedded in paraffin. The exact extension of the lamina elastica interna and the surface of the intima were determined for each cross section with an automatic planimeter (Graphic Tablet 911/A, Hewlett-Packard Company, Andover, Mass.).

The majority of LAD stenoses were found in the proximal part of the vessel, whereas these lesions, when present, were distributed along the whole length of the RGEA. The incidence and degree of stenosis in the LAD and RGEA are compared in Fig. 2. Some stenotic lesions were present in all patients: 4 of 37 patients were found to have an RGEA stenosis of greater than $50 \%$, but 27 of 37 patients had such lesions in the LAD. Surprisingly, there were additional unexpected findings: intimal thickening or up to $50 \%$ stenosis of the RGEA was seen in 33 of 37 patients, asymptomatic stenosis of the celiac trunk in 3 patients, and a severly diseased thoracic aorta (including ulcers, thrombi, and cholesterol wall deposits) in 12 of 37 patients In 2 patients, the gastroduodenal artery was narrowed as a consequence of chronic peptic ulcer disease.

Although all postmortem cases with atherosclerotic changes in RGEA had some degree of LAD involvement, no correlation could be found between these two arteries in terms of prevalence, location, and severity of the lesions. This observation is supported by the angiographic results of Sons and associates.

Studies of atherosclerosis of the IMA have demonstrated that the degree of atherosclerotic changes correlates well with the severity of coexistent peripheral vascular disease and hyperlipidemia or with age, hypertension, and vascular disease. ${ }^{9-11}$ These findings could not be confirmed in the present observation. In contrast to previous, more optimistic reports, we found comparable atherosclerosic lesions in the LAD and the RGEA in 1 of 10 patients. The RGEA seems to be affected significantly more often than the IMA. ${ }^{12}$ With increasing age, the development of atherosclerotic lesions seems to be accelerated in the RGEA more than in the LAD.

The prevalence of atherosclerosis in the RGEA should not preclude its use. However, because of the present article and several previous reports, caution is advised in patients older than 60 years who have diffuse coronary artery disease with extended peripheral lesions, in patients with hypertrophic myocardium, and in possible competitive flow situations. Preoperative assessment of the RGEA either by angiography or by size and flow measurements ${ }^{13}$ is recommended, at least in high-risk procedures.

\section{REFERENCES}

1. Suma H, Fukumoto H, Takeuchi A. Coronary artery bypass grafting by using in situ right gastroepiploic artery: basic study and clinical application. Ann Thorac Surg 1987;44:394-7.

2. Mills NL, Everson CT. Right gastroepiploic artery: a third arterial conduit for myocardial revascularization. Ann Thorac Surg 1989;47:706-11.

3. Van Son JA, Smidts F, Vincent JG, van Lier HJ, Kubat K. Comparative anatomic studies of various arterial conduits for myocardial revascularization. $\mathrm{J}$ Thorac Cardiovasc Surg 1990;99:703-7.

4. Tanimoto Y, Mitsuda T, Fujii B. Angiography of right gastroepiploic artery for coronary artery bypass grafts. Cathet Cardiovasc Diagn 1989;16:35-8.

5. Suma H, Wanibuchi Y, Terada Y, Fukuda S, Takayama T, Furuta $S$. The right gastroepiploic artery graft: clinical and angiographic mid-term results in 200 patients. J Thorac Cardiovasc Surg 1993;105:615-23.

6. Ishiki T, Yamaguchi T, Nakamura M. Postoperative angiographic evaluation of gastroepiploic artery grafts: technical considerations and short-term patency. Cathet Cardiovasc Diagn 1990;21:233-8.

7. Suma H, Takamashi R. Atherosclerosis of the gastroepiploic and internal thoracic arteries. Ann Thorac Surg 1990;50:413-6.

8. Domeisen H, Schneider J. Ausmass der Atherosklerose der Art. Gastroepiploica dextra und der Koronararterien bei Patienten über 30 Jahren: eine Autopsie-Studie. Zürich, 1992. Thesis.

9. Sons HJ, Godehardt E, Kunert J, Lösse B, Bircks W. Internal thoracic artery: prevalence of atherosclerotic changes. J Thorac Cardiovasc Surg 1993;105:1192-6.

10. Kay HR, Korns ME, Flemma RJ, Tector AJ, Lepley D. Atherosclerosis of the internal mammary artery. Ann Thorac Surg 1976;21:504-7.

11. Sisto T, Isola J. Incidence of atherosclerosis in the internal mammary artery. Ann Thorac Surg 1989;47: 884-6.

12. Jühlke M, von Segesser LK, Schneider J, Turina M, Heitz P. Ausmass der Arteriosklerose der Arteria mammaria interna und der Koronararterien bei Männern im Alter von 45 bis 75 Jahren. Schweiz Med Wochenschr 1989;119:1219-23.

13. Mills NL, Hochmuth DR, Everson CT, Robart CC. Right gastroepiploic artery used for coronary artery bypass grafting: evaluation of flow characteristics and size. J Thorac Cardiovasc SuRg 1993;106:579-86. 